\title{
Awareness, Knowledge and Attitude towards Bioethics among First Year Undergraduate students of a Health Science Institute in Eastern Nepal
}

\author{
Sumit Sharma ${ }^{1}$, Dhana Ratna Shakya ${ }^{2}$, Seema Adhikari ${ }^{1}$, Vivek Acharya Chetri $^{1}$, Rupa \\ Rajbhandari Singh ${ }^{3}$ \\ ${ }^{1}$ MBBS Students, \\ ${ }^{2}$ Professor, Department of Psychiatry, \\ ${ }^{3}$ Professor, Department of Pediatrics, \\ BP Koirala Institute of Health Sciences (BPKIHS), Dharan, Sunsari, Nepal. \\ Corresponding Author: Sumit Sharma \\ E-mail: mailtomesumit@gmail.com
}

\begin{abstract}
Background: Awareness, knowledge and attitude of the beginner of health science/medical education towards Bioethics and ethical principles will have a great bearing in the future career. We intended to assess the awareness, knowledge and attitude towards Bioethics and bioethical issues in Health Science/Medical students of BPKIHS in the beginning of their medical education. Methodology: This is an academic institute based study carried out among the first year undergraduate (BSc.-Nursing, BSc.- Allied, BDS and MBBS) students of B. P. Koirala Institute of Health Sciences (BPKIHS). We approached all students of the first year of the undergraduate programs of an academic year in BPKIHS. We got the responses from 181 subjects giving written informed consent. The 'semi-structured proforma' and the pretested 'Bioethics Awareness, Knowledge and Attitude' questionnaire were used to collect the responses.

Results: We had 55\% female subjects, more from urban settings (65\%). Students were from Nepal $(76.2 \%)$ and India (23.8\%). Many students were aware about Bioethics and willing to be a part of Bioethics group. Many students were not aware about the regulatory body giving permission to practice medicine and to conduct clinical trial in Nepal. Majority of the subjects viewed knowledge of ethics very important and wanted to become part of a Bioethics group. More than one fourth participants agreed on the view that health professionals know the best irrespective of patient opinion. Most of the participants believed that patient's wishes should always be adhered to. A few respondent students (4\%) also believed that doctors and nurses should refuse to treat violent patients. Majority of the participants had heard of taking informed consent and agreed on entertaining patient's questions during their posting. Almost half of the participants agreed on Bioethics education and research methodology should be a part of UG curriculum.

Conclusions: There should be various modes of enhancing the teaching learning opportunities for the medical students to learn about ethics and ethical principles and to enhance their positive view. Key words: Awareness, Attitude, Bioethics, Knowledge, Medical students, Nepal
\end{abstract}

\section{Introduction}

Biomedical ethics or in short, 'Bio-ethics' is the study of moral values and judgments applied to medicine. Conceptually, it is a shared reflective examination of the issues in health-care (service), health science (academics and research) and health policy as right and wrong, with indication of 
what to do and what not to [1]. The medical ethics education has been shown to have a positive impact on moral development and on making complete and better doctors [2]. Studies have revealed that most of the knowledge of biomedical ethics is acquired during the undergraduate training [3]. However, most of the students do not receive enough training to sufficiently prepare them for the ethical challenges they face in practice [4]. Medical ethics, a part of bioethics is included and is being taught under Forensic medicine to the medical undergraduates in most medical schools including B. P. Koirala Institute of Health Sciences (BPKIHS).

With the advancing Science and Technologies, there has been great leap by medical and paramedical sectors, so have ethical dilemmas and litigations against health personnel regarding ethical issues. The western societies, working within their own value system, may have been able to develop a 'near consensus' on how to deal with at least some of the thorny bio-ethical questions [5]. However, the Nepalese society, is yet to deliberate upon new bioethical questions in accordance with its own, unique socio-cultural and religious practices. There have been some attempts in the field of Bioethics in Nepal which are largely unorganized. Nepal National Unit of UNESCO Chair on Bioethics joined the UNESCO chair on Bioethics global network in January 23, 2014 and has been constantly working in the field of Bioethics since its establishment [6].

It is important to train, sensitize especially the medical professionals regarding the ethics. With these viewpoints, this research was conducted to assess the awareness, Knowledge and attitude of Bioethics among first year undergraduate students who are just beginning their study in the Health Science fields.

\section{Methodology}

This is an academic institute based descriptive study carried out among the first year undergraduate students from Medical, Dental, Nursing and allied fields (i.e. BSc.- Nursing, BSc.- Allied, BDS and MBBS) of BPKIHS. BPKIHS has a total of 1527 students in various academic programs of Bachelor (MBBS, BDS, BSc.- Nursing, BSc. MIT), Master level (MD, MS, MDS, MSc Basic Sciences, MSc Nursing, MPH and MDHA) and Subspecialty programs in DM (Cardiology, Gastroenterology and Hepatology, Pulmonary, Critical care and Sleep Medicine, Neonatology) and MCH (Urology, GI Surgery) in academic year of 2019/20 in its 4 colleges: Medical, Dental, Nursing and Public Health. Its Teaching Hospital currently has 815 beds and well established major Clinical and Basic Science departments. This WHO Directory recognized health science institute adopts the concept of Teaching District Hospitals; currently serving 10 districts [7].

We approached all of the 210 students enrolled in these academic programs in the academic year of 2016 in BPKIHS [8]. The subjects were approached in person to explain about the study, written informed consent was collected, the 'semi-structured proforma' and the pretested 'Bioethics Awareness, Knowledge and Attitude' questionnaire were used to collect the related responses through face-to-face interview or through self-response. Up to maximum of 3 times, the subjects were contacted if required. Candidates not available during the study period were excluded. We could collect the responses of 181 subjects within the study period. The responses were then analyzed focusing on Knowledge, Awareness and attitude regarding Bioethics.

\section{Results}

Table 1: Socio-demographic Information

\begin{tabular}{|c|c|}
\hline Attribute & Frequency (\%) \\
\hline \multicolumn{2}{|c|}{ Sex } \\
\hline Male & $81(44.8)$ \\
\hline Female & $100(55.2)$ \\
\hline \multicolumn{2}{|c|}{ Nationality } \\
\hline Indian & $43(23.8)$ \\
\hline Nepalese & $138(76.2)$ \\
\hline \multicolumn{2}{|l|}{ Residential Area } \\
\hline Urban & $118(65.2)$ \\
\hline
\end{tabular}




\begin{tabular}{|l|l|}
\hline Semi-Urban & $43(23.8)$ \\
\hline Rural & $20(11.0)$ \\
\hline \multicolumn{2}{|c|}{ Religion } \\
\hline Buddhist & $2(1.1)$ \\
\hline Christian & $3(1.7)$ \\
\hline Hindu & $176(97.2)$ \\
\hline Total & 181 \\
\hline
\end{tabular}

Table 2: Questions on Awareness of Bioethics with their responses

\begin{tabular}{|l|l|l|}
\hline Questions & Yes & No \\
\hline Have you heard the term 'Bioethics'? & $161(89 \%)$ & $20(11 \%)$ \\
\hline $\begin{array}{l}\text { Would you be interested in educating yourself in } \\
\text { Bioethics? }\end{array}$ & $162(89.5 \%)$ & $19(10.5 \%)$ \\
\hline $\begin{array}{l}\text { Are you aware about the bioethics group in your } \\
\text { institute? }\end{array}$ & $59(32.6 \%)$ & $122(67.4 \%)$ \\
\hline Would you like to become part of bioethics group? & $144(79.6 \%)$ & $37(29.4 \%)$ \\
\hline Do you know what an ethical dilemma is? & $86(47.5 \%)$ & $95(52.5 \%)$ \\
\hline
\end{tabular}

Table 3: Views on different Bioethical Issues faced by Medical and Paramedical students

\begin{tabular}{|c|c|c|c|c|c|c|}
\hline Questions & $\begin{array}{l}\text { Strongly } \\
\text { Disagree }\end{array}$ & Disagree & Not Sure & Agree & $\begin{array}{l}\text { Strongly } \\
\text { Agree }\end{array}$ & Total \\
\hline $\begin{array}{l}\text { Health Professionals know the } \\
\text { best irrespective of patient } \\
\text { opinion. }\end{array}$ & $\begin{array}{c}22 \\
(12.2 \%)\end{array}$ & $\begin{array}{c}53 \\
(29.3 \%)\end{array}$ & $\begin{array}{c}51 \\
(28.2 \%)\end{array}$ & $47(26 \%)$ & $(4.4 \%)$ & $\begin{array}{c}181 \\
(100 \%)\end{array}$ \\
\hline $\begin{array}{l}\text { Patient should always be } \\
\text { informed of wrong doing by } \\
\text { medical personnel. }\end{array}$ & & ) & $\begin{array}{c}22 \\
(12.2 \%)\end{array}$ & $\begin{array}{c}97 \\
(53.6 \%)\end{array}$ & $\begin{array}{c}47 \\
(26 \%)\end{array}$ & $\begin{array}{c}181 \\
(100 \%)\end{array}$ \\
\hline $\begin{array}{l}\text { wishes should always be } \\
\text { to. }\end{array}$ & $(220 / 0)$ & $\begin{array}{c}31 \\
(17.1 \%)\end{array}$ & $\begin{array}{c}44 \\
(24.3 \%)\end{array}$ & $\begin{array}{c}72 \\
(39.8 \%)\end{array}$ & $\begin{array}{c}30 \\
(16.6 \%)\end{array}$ & $\begin{array}{c}181 \\
(100 \%)\end{array}$ \\
\hline $\begin{array}{l}\text { Confidentiality can't be } \\
\text { maintained in modern care and } \\
\text { should be abandoned. }\end{array}$ & $\begin{array}{c}52 \\
(28.9 \%)\end{array}$ & $\begin{array}{c}69 \\
(38.1 \%)\end{array}$ & $\begin{array}{c}42 \\
(23.2 \%)\end{array}$ & $13(7.2 \%)$ & o) & $\begin{array}{c}181 \\
(100 \%)\end{array}$ \\
\hline $\begin{array}{l}\text { Certain medical professional } \\
\text { charge more from rich patient to } \\
\text { compensate for treating the poor. }\end{array}$ & $\begin{array}{c}26 \\
(14.4 \%)\end{array}$ & $\begin{array}{c}39 \\
(19.9 \%)\end{array}$ & $\begin{array}{c}68 \\
(37.6 \%)\end{array}$ & $\begin{array}{c}40 \\
(22.1 \%)\end{array}$ & $\begin{array}{c}11 \\
(6.1 \%)\end{array}$ & $\begin{array}{c}181 \\
(100 \%)\end{array}$ \\
\hline $\begin{array}{l}\text { Ethical conduct is important only } \\
\text { for avoiding legal action. }\end{array}$ & $\begin{array}{c}27 \\
(14.9 \%)\end{array}$ & $\begin{array}{c}71 \\
(39.2 \%)\end{array}$ & $\begin{array}{c}44 \\
(24.3 \%)\end{array}$ & $\begin{array}{c}32 \\
(17.7 \%)\end{array}$ & $7(3.9 \%)$ & $\begin{array}{c}181 \\
(100 \%)\end{array}$ \\
\hline $\begin{array}{l}\text { Do you think that Bioethics } \\
\text { education and research } \\
\text { methodology should be a part of } \\
\text { UG curriculum? }\end{array}$ & $(2.2 \%)$ & $7(3.9 \%)$ & $\begin{array}{c}32 \\
(17.7 \%)\end{array}$ & $\begin{array}{c}88 \\
(48.6 \%)\end{array}$ & $\begin{array}{c}50 \\
(27.6 \%)\end{array}$ & $\begin{array}{c}181 \\
(100 \%)\end{array}$ \\
\hline $\begin{array}{l}\text { Children should never be treated } \\
\text { without consent of parent. }\end{array}$ & $8(0.4 \%)$ & $\begin{array}{c}24 \\
(13.3 \%)\end{array}$ & $\begin{array}{c}33 \\
(18.2 \%)\end{array}$ & $\begin{array}{c}82 \\
(45.3 \%)\end{array}$ & $\begin{array}{c}34 \\
(18.8 \%)\end{array}$ & $\begin{array}{c}181 \\
(100 \%)\end{array}$ \\
\hline $\begin{array}{l}\text { Decision taken in western setup } \\
\text { will be applicable in our setup. }\end{array}$ & $\begin{array}{c}10 \\
(5.5 \%)\end{array}$ & $\begin{array}{c}60 \\
(33.1 \%)\end{array}$ & $\begin{array}{c}74 \\
(40.9 \%)\end{array}$ & $\begin{array}{c}32 \\
(17.7 \%)\end{array}$ & $5(2.8 \%)$ & $\begin{array}{c}181 \\
(100 \%)\end{array}$ \\
\hline $\begin{array}{l}\text { Doctors and Nurses should refuse } \\
\text { to treat violent patient. }\end{array}$ & $\begin{array}{c}62 \\
(34.3 \%)\end{array}$ & $\begin{array}{c}80 \\
(44.2 \%)\end{array}$ & $\begin{array}{c}31 \\
(17.1 \%)\end{array}$ & $7(3.9 \%)$ & $1(0.6 \%)$ & $\begin{array}{c}181 \\
(100 \%)\end{array}$ \\
\hline
\end{tabular}




\section{Discussion}

This is a descriptive study which examined the awareness, knowledge and attitude of the undergraduate students in the beginning of their study. To our notice, this study is the first of its kind being done at our institute focusing on the Undergraduate students who are the future of the medical practice in Nepal. The study was carried out under the guidance of the Nepal National Unit of UNESCO Chair in Bioethics.

Majority of our participants (89\%) had heard the term 'Bioethics'. This figure is comparable to other study among graduate students and faculty/ researchers of universities in Lahore, Pakistan by Alam and others where $88.9 \%$ of the participants were familiar with the term 'Bioethics' [9]. The awareness regarding Bioethics may be due to the sensitization programs carried out by the Bioethics Unit at BPKIHS among the first-year undergraduate students and also the different bioethical issues that they come across in the news and medias.

Only $1.1 \%$ of the participants thought that the knowledge of Bioethics to them and their work is not at all important and $89.5 \%$ of the participants were interested in educating themselves in Bioethics. This figure is comparable to a study conducted among medical and dental postgraduate in south India by Janakiram and others where $1.8 \%$ of the medical postgraduate and none of the dental postgraduate thought that knowledge of medical ethics is not at all important to their work [10].

Thirds of the subjects (67.4\%) were not aware about the Bioethics group in their institution although $79.6 \%$ of the participants wanted to become part of the Bioethics group in their institution. This shows that although many of the undergraduates wanted to gain knowledge and training about Bioethics, they were not able to do so due to lack of proper place to achieve the training. Many (43.6 \%) participants acquired their knowledge in Bioethics through lectures and seminar and only $14.9 \%$ acquired their knowledge through training. This indicates that Bioethics group in this institute should organize more trainings and seminars and proper publicity of the group and events organized by the group should be done.

In our study, only $21.5 \%$ of the participants knew about the ethics committee in the institution. In contrast to the finding of the present study, the study conducted among medical and dental post graduate students in South India by Janakiram and others showed that nearly $98 \%$ of the medical participants and $79 \%$ of the dental participants knew that their institution had an ethical committee [10]. This difference can be due to the study population. Our study focused on the first year Undergraduate students who were in the beginning of medical career and had less knowledge and experience compared to the post graduate students in the same field.

Many (41.4\%) participants didn't know about the content of Hippocratic Oath, 35.9\% of the participants didn't know about the regulatory body in Nepal that gives permission for the practice in their respective field and more than half of the participants didn't know about the regulatory body in Nepal that gives permission for clinical trial of new medicine in our country. This shows the need of educating the beginners of the undergraduate Medical, Dental, BSc. Nursing and BSc. MIT students who are the future of the medical field of Nepal. Although the Department of Forensic medicine is teaching students about Medical ethics, Medical Jurisprudence is focused more with not much importance given to other broad aspects of Bioethics. So, more emphasis on Bioethics is needed in curriculum of undergraduate in the medical profession.

Participants had mixed type of attitude towards some bioethical issues. More than one fourth of the participants agreed on the view that health professionals know the best irrespective of patient opinion while more than one fourth disagreed on this view, more one fourth were not sure about this view. This variety in view may be because of the still deep-rooted patriarchal type of medical practice which is slowly fading away with increasing awareness of students on ethics and rising literacy status of the Nepalese population.

More than one third of the participants disagreed and more than one fourth strongly disagreed on the argument that confidentiality can't be maintained in modern care and should be abandoned. This shows the enthusiasm of future medical professionals of Nepal in maintaining the confidentiality and respecting them which is a good indicator in the field of bioethics. On the other hand, almost half of the participants agreed on Bioethics education and research methodology 
should be a part of UG curriculum, which portrays the increasing interest and curiosity among students about the bioethics topics.

This study has some limitations. Our study had only first year undergraduates as participants. The results, hence, may not be generalized to the whole undergraduate students. First year students have only little clinical exposure. So, most of the students had not faced ethical dilemma and were most likely unfamiliar about Bioethics. With the findings of current study, we strongly recommend that medical education policy should be revised to include bioethics education to inculcate ethical attitude and behavior in students. There should be proper training in bioethics targeting the undergraduates and post graduates. More similar study needs to be conducted here focusing medical interns and faculties to access their level of attitude and practice as in other parts [11-12].

\section{Conclusions}

Our study brings about the attention to the importance of knowledge, awareness and attitude towards Bioethics in the students of undergraduate level. This study showed that most of the students were aware about Bioethics but not much of them had deep knowledge about its importance in modern day medicine. Variability in the attitude towards different bioethical issues was found but they were more curious to learn about bioethics and wanted bioethics to be the part of their curriculum. If the students are sensitized on various bioethical issues right from the beginning of their carrier, it would be very beneficial in the future and would guide the students to take the more ethical decision as a future medical professional.

\section{List of abbreviations \\ BPKIHS- B. P. Koirala Institute of Health Sciences}

\section{Declarations}

\section{Ethics approval and consent to participate}

The study was done after obtaining the approval of Department Research Unit (DRU) of Department of Pediatrics under Institutional Research Committee of BPKIHS (IRC). The IRC is affiliated to Nepal Heal Research council (NHRC). Cases were enrolled after informed written consent from the subject. Strict confidentiality of information was maintained.

Consent for publication: Not applicable.

Competing interests: The authors declare that they have no competing interests.

Authors' contributions: DRS and SS were involved in all steps. RRS, SA and VAC were involved in research designing, assisting data collection and editing. All authors read and approved the final manuscript.

\section{REFERENCES}

1. Shakya DR, Singh RR, Shrestha RR. Bioethics for the Welfare of the Health Service Provider and Consumer. Global Bioethics Enquiry 2015;4:55-62.

2. Hariharan S, Jonnalagadda R, Walrond E, and Moseley H. Knowledge, attitude and practice of healthcare ethics and law among doctors and nurses in Barbados. BMC Medical Ethics 2006;7:7.

3. Hernández González A, Rodríguez Núñez A, CambraLasaosa FJ, Quintero Otero S, RamilFraga C, García Palacios MV. Knowledge of health care ethics in paediatric residents. An Pediatric (Barc) 2014;80(2):106-13.

4. Mohamed A. M, Ghanem M. A and Kassem A. A. Knowledge, perceptions and practices towards medical ethics among physician residents of University of Alexandria hospitals, Egypt. Eastern Mediterranean Health Journal 2012;18(9):935-45.

5. Nepal Unit of the International Network of the UNESCO Chair in Bioethics. http://www.unescochair- bioethics.org/UI/C02.aspx View publication

6. Alam M, Rahman Z, Shah M, Zar MS, Shams S, Ali F, et al. Bioethics: Awareness, attitudes and opinions among University students and Faculty/Researchers. Pak J Med Sci 2012;28(4):680-5.

7. Shakya DR, Mishra DR, Gyawali R, Rimal SP, Lama S, Yadav AK, Nepal S, Pokharel B, Sapkota N. COVID-19 pandemic and BPKIHS: our Situation, Endeavours and Future direction. J BPKIHS 
2020;3(1):39-49.

8. Dean Academics of BPKIHS: www.bpkihs.edu

9. Ilyas M, Alam M, Ahmad H, Tariq M, Bibi S, Ali A, et al. Awareness regarding bioethical issues among the students \& faculty of Hazara University Mansehra, Pakistan. Pak J Med Sci 2009;25(1): 97-102.

10. Janakiram C, Gardens SJ. Knowledge, attitudes and practices related to healthcare ethics among medical and dental postgraduate students in south India. Indian J Med Ethics 2014;11(2):99-104.

11. Aacharya RP, Shakya YL. Knowledge, attitude and practice of medical ethics among medical intern students in a Medical College in Kathmandu. Bangladesh J Bioethics 2015;6(3):1-9.

12. Rose A, George K, Dhas TA, Pulimood AB, Kang G. Survey of ethical issues reported by Indian medical students: basis for design of a new curriculum. Indian J Med Ethics 2014;11(1):25-8.

Acknowledgements: Dean Academics, BPKIHS and BPKIHS Research Committee.

Funding: None. The authors, however, declare that they received logistic support from BPKIHS research committee.

Conflict of interest: Nil 